\title{
Pyrite textures and compositions from the Qiucun Au deposit, Dehua-Youxi- Yongtai ore district, SE China: implication for ore-forming processes
}

\section{FEIPENG FAN ${ }^{1}$, FAN XIAO $^{1}$, SHIZHONG CHEN ${ }^{1}$, GUANGFU XING ${ }^{2}$ AND SIDA NIU ${ }^{3}$}

${ }^{1}$ Nanjing Center, China Geological Survey

${ }^{2}$ Wuhan Center, China Geological Survey

${ }^{3}$ Institute of Mineral Resources Research, China Metallurgical Geology Bureau

Presenting Author: fanfp1111@163.com

The Qiucun Au Deposit is a typical low-sulfidation epithermal gold deposit in central Fujian Province, with pyrite as the main ore mineral. Pyrite is favourable for deciphering hydrothermal and ore-forming processes. Based on optical characteristics, BSE observation and NanoSIMS mapping, four generations of zoned pyrite was determined, including the pyrite with Nos. of 2, 1, and 0 at an early stage and Pyrite 3 at the main ore-forming stage. Among them, Pyrite 0 is irregular and has low concentrations of $\mathrm{As}, \mathrm{Sb}, \mathrm{Au}, \mathrm{Ag}, \mathrm{Pb}, \mathrm{Zn}$, and $\mathrm{Cu}$. Pyrite 1 precipitated with Pyrite 0 and shows oscillatory zoning, of which the slightly bright edges have high content of $\mathrm{As}, \mathrm{Ag}, \mathrm{Sb}$, and $\mathrm{Cu}$ while the dark bands have low content of $\mathrm{As}, \mathrm{Au}, \mathrm{Ag}, \mathrm{Pb}, \mathrm{Zn}$, and $\mathrm{Cu}$. Pyrite 2 precipitated with Pyrite 1 and also shows oscillatory zoning, of which the bright edges have high content of $\mathrm{As}, \mathrm{Au}, \mathrm{Ag}, \mathrm{Sb}, \mathrm{Cu}$, $\mathrm{Pb}$, and $\mathrm{Zn}$. The oscillatory zoning represents the separation of fluid phase with ore-forming elements that occurred around the crystals of Pyrite 1. Pyrite 3 is on the edge of Pyrite 2 and along cracks of pyrite that occurs with sphalerite, galena, chalcopyrite, and electrum. The pyrite was likely crushed due to a tectonicmagmatic event and then Au-rich hydrothermal fluids filled into its cracks. The $\delta^{34} \mathrm{~S}$ values of the pyrite suggest a magmatic sulfur source. The Rb-Sr geochronological age of the epithermal pyrite from adjacent Donghua is $153.7 \pm 2.4 \mathrm{Ma}^{[1]}$, and the ReOs isochron age of the molybdenite in adjacent Qiucheng Mo Deposit is $150.8 \pm 1.6 \mathrm{Ma}^{[2]}$, suggesting that the gold metallogenic event was coincident with the tectonic-magmatic event around $150 \mathrm{Ma}$ that is related to the subduction of the Pacific Plate.

\section{Acknowledgements}

This study is funded by the National Key R\&D Program of China (Grant No.: 2016YFC0600210) and a project initiated by the China Geology Survey (No.: DD20190153).

\section{References}

[1] Niu S.D., Guo J., Xing G.F., et al. (2020), Ore Geology Reviews, 126.

[2] Fan, F.P., Xiao, F., Xiang, H.L., et al. (2020), China Geol. 1-15 (in Chinese with English abstract).

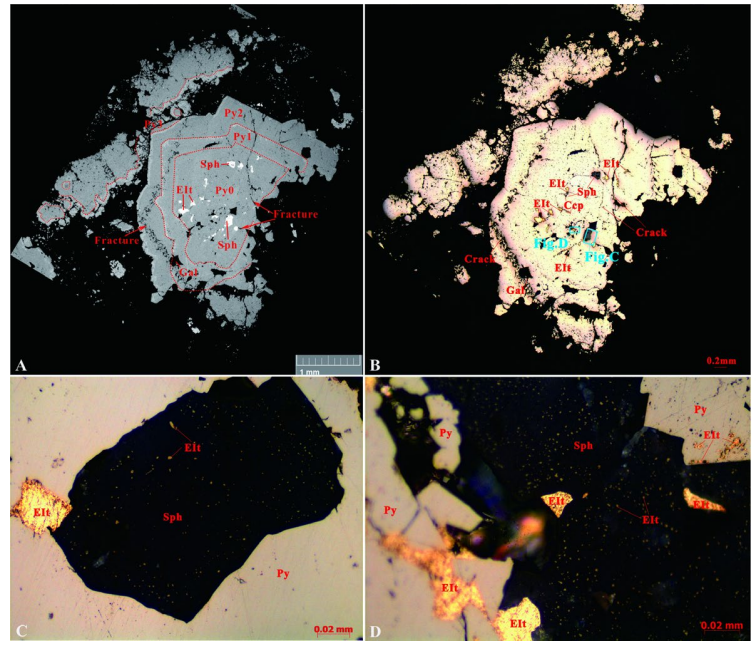

